\title{
ABO/RH DISTRIBUTION PATTERN AND PREVALENCE OF IRREGULAR ANTIBODIES IN HEALTHY BLOOD DONORS OF UTTARAKHAND
}

\author{
Brijesh Thakur1, Sanjay Kaushik2, Sanjeev Kishore², Rajnish Kumar', Anil Rajput ${ }^{5}$
}

${ }^{1}$ Assistant Professor, Department of Pathology, SGRRIM \& HS, Dehradun.

${ }^{2}$ Associate Professor, Department of Pathology, SGRRIM \& HS, Dehradun.

3 Professor \& HOD, Department of Pathology, SGRRIM \& HS, Dehradun.

${ }^{4}$ Professor, Department of Pathology, SGRRIM \& HS, Dehradun.

$53^{\text {rd }}$ Year Resident, Department of Pathology, SGRRIM \& HS, Dehradun.

\begin{tabular}{l}
\hline ABSTRACT \\
\hline BACKGROUND \\
Blood group plays a vital role in transfusion safety, understanding genetics, inheritance pattern and disease susceptibility. This \\
study is aimed to determine distribution pattern of ABO and Rh blood group, incidence and identification of irregular antibodies \\
among blood donors of Uttarakhand.
\end{tabular}

\section{METHOD}

$\mathrm{ABO} / \mathrm{Rh}$ blood grouping was performed by test tube agglutination method (both cell and serum grouping) using antisera $\mathrm{A}, \mathrm{B}$ and Rh from Tulip and Orthodiagnostics. Donors' plasma were screened for irregular antibodies by indirect antiglobulin technique using Bio-Rad ID-Card "LISS/Coombs" and test cell reagents "ID-DiaCell” via gel centrifugation.

\section{RESULTS}

Out of total 4573 included blood donors, $88.2 \%$ were males. The maximum blood donors (77.6\%) were in $18-25$ years of age group. The commonest ABO blood group present was B (36.1\%) followed by 0 (29.1\%), A (24.8\%) and AB (10\%) in blood donors; while in Rhesus system, 95.0\% donors were Rh-positive and 5.0\% donors were Rh negative. Screening of donors' plasma did not reveal any detectable irregular antibody.

\section{CONCLUSION}

The study has a significant implication in suggesting the distribution pattern of ABO/Rh blood group typing in the region, but routine irregular antibody screening in healthy blood donors may not be fruitful in this region keeping cost effectiveness and absence of previous sensitization in mind.

\section{KEYWORDS}

Transfusion, Irregular, Antibody, ABO/Rh, Donor.

HOW TO CITE THIS ARTICLE: Thakur B, Kaushik S, Kishore S, et al. ABO/Rh distribution pattern and prevalence of irregular antibodies in healthy blood donors of Uttarakhand. J. Evolution Med. Dent. Sci. 2016;5(56):3852-3856, DOI: $10.14260 /$ jemds/2016/882

\section{INTRODUCTION}

It was recorded in the Bible that the "life of the flesh was in the blood." Many lives are saved throughout the world each year through the use of blood transfusions, by preventing death from loss of blood due to trauma and by allowing performance of surgical procedures which would otherwise be impossible. Knowledge about the distribution of $\mathrm{ABO}-\mathrm{Rh}$ blood groups in a region is helpful in effective management of blood banks inventory. Also irregular erythrocyte antibodies can cause transfusion reactions resulting in fever, chills, destruction of RBC's and haemolysis in recipients. The present study aimed to determine the distribution pattern of $\mathrm{ABO} / \mathrm{Rh}$ blood grouping and incidence as well as identification of irregular antibodies in healthy blood donors of Uttarakhand region.

Financial or Other, Competing Interest: None.

Submission 06-06-2016, Peer Review 02-07-2016,

Acceptance 07-07-2016, Published 13-07-2016.

Corresponding Author:

Dr. Brijesh Thakur

Assistant Professor

Department of Pathology,

SGRRIM \& HS,

Patel Nagar,

Dehradun-248001.

E-mail: drbrijeshthakur03@gmail.com

DOI: $10.14260 /$ jemds/2016/882

\section{MATERIAL AND METHODS}

The present study included the blood donors who donated blood in the hospital blood bank as well as at various blood donation camps from January 2013 to June 2014. The study had been approved by Institutional Ethical Committee. A pretested proforma was used which included donor's name, age, sex, religion, occupation, educational status, socioeconomic status, marital status, family history and routine physical examination findings. Inclusion criteria includes age of donor ranging from 18-65 years, weight $>45$ kgms and haemoglobin equal or more than $12.5 \mathrm{gm} / \mathrm{dL}$. Individuals suffering from the diseases like cancer, epilepsy, heart disease, bleeding disorder, diabetes, hepatitis, AIDS and TB were excluded as donors from the study. Donors with recent history of abortions, blood transfusion, tattooing, surgery, typhoid, malaria or vaccination were temporarily deferred from blood donation. Professional donors, drug addicts or individuals with multiple sex partners were excluded from the study.

Screening tests for HIV, HCV, HbsAg using Tri-Dot card test, VDRL using Transasia TP card test and MP-antigen using SD Rapid test kit for Malaria Ag Pf/Pan (HRP-II/pLDH) were performed. The $\mathrm{ABO}$ and $\mathrm{Rh}$ blood grouping of blood donors were performed by test tube method (Both forward and 
reverse) using antisera A, B and Rh from Tulip. Donors' plasma were screened for irregular antibodies by indirect antiglobulin technique using Bio-Rad ID-Card "LISS/Coombs" and test cell reagents "ID-DiaCell" via gel centrifugation. Known positive and negative controls for blood grouping as well as irregular antibodies were run in parallel with tests.

\section{RESULTS}

Out of total 4661 blood donations, 88 donors who tested positive during screening tests were excluded. The prevalence of seropositivity for HIV, HCV, HbsAG, VDRL and MP-AG among blood donors was $0.19 \%, 0.47 \%, 0.77 \%, 0.45 \%$ and $0 \%$ respectively. The study included total 4573 healthy blood donors. Out of these $434(9.5 \%)$ donated blood at hospital as a replacement and 4139 (90.5\%) donated at camps voluntarily.

During the study, younger age group (18-25 years) contributed about $77.6 \%(3548 / 4573)$ of the total blood donations followed by 25-35, 35-45 and >45 years of age groups accounting for $12 \%$ (549/4573), 09\% (412/4573) and $1.4 \%$ (64/4573) respectively. Male predominance in blood donation accounting for $88.1 \%$ (4033/4573) was observed as compared to the females contributing only $11.9 \%$ (540/4573) of the total donations. Male:Female ratio was approx. 7.5:1.

In the present study (Table 1), the overall commonest blood group was 'B' contributing 36.1\% (1653/4573) followed by blood group ' $O$ ' in $29.1 \%(1329 / 4573)$, ' $A$ ' in $24.8 \%$ (1134/4573) and ' $A B$ ' in 10\% (457/4573) of the total included donors. In male donors, $\mathrm{ABO}$ grouping followed the same frequency pattern $(B>0>A>A B)$. Although, also in female donors 'B' was most common blood group contributing for $4 \%$ (181/4573); however, blood groups ' $O$ ' and 'A' showed insignificant difference in their frequency accounting for 3.5\% and $3.15 \%$ respectively.

Blood group ' $\mathrm{AB}$ ' was least common in both genders contributing $8.9 \%$ and $1.0 \%$ of the total donors. The overall positivity of Rh blood group was $95.0 \%$ (4345/4573), while $\mathrm{Rh}$ negative blood group accounted for $5.0 \%$ (228/4573) of the total donors. Male donors accounted for $83.92 \%$ (3838/4573) of this positivity, while female donors for $11.08 \%$ (507/4573). Screening of donors' plasma did not show any positive clinically significant irregular antibodies.

\begin{tabular}{|c|c|c|c|c|c|c|}
\hline \multirow{2}{*}{$\begin{array}{c}\text { ABO } \\
\text { Blood } \\
\text { Group }\end{array}$} & \multicolumn{2}{|c|}{ Male } & \multicolumn{2}{|c|}{ Female } & \multicolumn{2}{|c|}{ Total } \\
\hline & $\begin{array}{l}\mathrm{Rh}+ \\
\text { (\%) }\end{array}$ & $\begin{array}{l}\text { Rh - } \\
\text { (\%) }\end{array}$ & $\begin{array}{l}\mathrm{Rh}+ \\
\text { (\%) }\end{array}$ & $\begin{array}{l}\text { Rh - } \\
\text { (\%) }\end{array}$ & $\begin{array}{l}\mathrm{Rh}+ \\
\text { (\%) }\end{array}$ & $\begin{array}{l}\text { Rh - } \\
\text { (\%) }\end{array}$ \\
\hline A & $\begin{array}{c}928 \\
(20.3)\end{array}$ & $\begin{array}{c}51 \\
(1.1)\end{array}$ & $\begin{array}{c}148 \\
(3.2)\end{array}$ & $\begin{array}{c}07 \\
(0.15)\end{array}$ & $\begin{array}{c}1076 \\
(23.5)\end{array}$ & $\begin{array}{c}58 \\
(1.25)\end{array}$ \\
\hline B & $\begin{array}{c}1396 \\
(30.5)\end{array}$ & $\begin{array}{c}76 \\
(1.7)\end{array}$ & $\begin{array}{c}170 \\
(3.7)\end{array}$ & $\begin{array}{c}11 \\
(0.2)\end{array}$ & $\begin{array}{c}1566 \\
(34.2)\end{array}$ & $\begin{array}{c}87 \\
(1.9)\end{array}$ \\
\hline $\mathrm{AB}$ & $\begin{array}{c}394 \\
(8.6)\end{array}$ & $\begin{array}{c}17 \\
(0.4)\end{array}$ & $\begin{array}{c}45 \\
(1.0)\end{array}$ & $\begin{array}{c}01 \\
(0.02)\end{array}$ & $\begin{array}{c}439 \\
(9.6)\end{array}$ & $\begin{array}{c}18 \\
(0.42)\end{array}$ \\
\hline 0 & $\begin{array}{c}1120 \\
(24.5)\end{array}$ & $\begin{array}{c}51 \\
(1.12)\end{array}$ & $\begin{array}{c}144 \\
(3.2)\end{array}$ & $\begin{array}{c}14 \\
(0.31)\end{array}$ & $\begin{array}{c}1264 \\
(27.7)\end{array}$ & $\begin{array}{c}65 \\
(1.43)\end{array}$ \\
\hline Total & $\begin{array}{c}3838 \\
(83.9)\end{array}$ & $\begin{array}{c}195 \\
(4.32)\end{array}$ & $\begin{array}{c}507 \\
(11.1)\end{array}$ & $\begin{array}{c}33 \\
(0.68)\end{array}$ & $\begin{array}{c}4345 \\
(95.0)\end{array}$ & $\begin{array}{c}228 \\
(5.0)\end{array}$ \\
\hline & :Sex- & $\begin{array}{l}\text { e Dist } \\
\text { tems }\end{array}$ & ution 0 & $\overline{B O \& R}$ & lood & \\
\hline
\end{tabular}

\begin{tabular}{|c|c|c|c|c|c|c|}
\hline Place of Study & $A(\%)$ & B (\%) & AB (\%) & $0(\%)$ & $\mathrm{Rh}+(\%)$ & $\mathbf{R h}-(\%)$ \\
\hline \multicolumn{7}{|l|}{ Within India } \\
\hline Ahmedabad. ${ }^{1}$ & 21.94 & 39.40 & 7.86 & 30.79 & 95.05 & 4.95 \\
\hline Jammu. $^{2}$ & 24.77 & 34.85 & 9.73 & 30.64 & 94.52 & 5.48 \\
\hline Latur. $^{3}$ & 24.89 & 37.98 & 9.47 & 27.64 & 95.19 & 4.81 \\
\hline U.P. ${ }^{4}$ & 21.94 & 35.66 & 9.73 & 32.67 & 95.75 & 4.25 \\
\hline Jaunpur (U.P.). ${ }^{5}$ & 24.6 & 33.0 & 7.9 & 34.5 & 99.01 & 0.99 \\
\hline Uttaranchal. ${ }^{6}$ & 33.80 & 23.0 & 7.98 & 35.21 & 96.71 & 3.28 \\
\hline West Bengal.7 & 22.65 & 34.87 & 6.68 & 35.8 & 97.7 & 2.3 \\
\hline Jodhpur. ${ }^{8}$ & 22.2 & 36.4 & 9.4 & 31.7 & 91.75 & 8.25 \\
\hline Amravati. ${ }^{9}$ & 27.02 & 33.06 & 8.33 & 31.04 & 95.74 & 04.26 \\
\hline \multicolumn{7}{|l|}{ Karnataka. ${ }^{10}$} \\
\hline Male & 19.87 & 36.86 & 7.05 & 36.22 & 94.57 & 5.13 \\
\hline Female & 23.6 & 33.00 & 5.9 & 37.50 & 94.44 & 5.66 \\
\hline Vellore. ${ }^{11}$ & 18.85 & 32.69 & 5.27 & 38.75 & 94.53 & 5.47 \\
\hline Indore. 12 & 24.15 & 35.25 & 9.10 & 31.50 & 95.43 & 4.57 \\
\hline Present Study & 24.8 & 36.2 & 10.0 & 29.0 & 95.01 & 04.99 \\
\hline \multicolumn{7}{|l|}{ Outside of India } \\
\hline Pakistan. ${ }^{13}$ & 21.92 & 36.95 & 7.33 & 33.8 & 92.17 & 7.83 \\
\hline Bangladesh. ${ }^{14}$ & 23.5 & 39.8 & 9.2 & 27.6 & 97.4 & 2.6 \\
\hline Nepal.15 & 34 & 29 & 4.0 & 33 & 96.7 & 3.3 \\
\hline Nigeria. ${ }^{16}$ & 26.9 & 16.1 & 4.2 & 52.9 & 91.7 & 8.3 \\
\hline Sudan. ${ }^{17}$ & 23.3 & 13.2 & 10.8 & 52.7 & 98.0 & 2.0 \\
\hline Turkey. 18 & 44 & 16.2 & 6.5 & 33.3 & 88.2 & 11.8 \\
\hline Iran. ${ }^{19}$ & 27 & 30.6 & 12 & 30.4 & 85.9 & 14.1 \\
\hline USA. ${ }^{20}$ & 41 & 09 & 04 & 46 & 85 & 15 \\
\hline Britain. $^{21}$ & 41.7 & 8.6 & 03 & 46.7 & 83 & 17 \\
\hline
\end{tabular}




\begin{tabular}{|c|c|c|}
\hline Study Done by & Study Group & Incidence \\
\hline Pahuja et al ${ }^{22}$ & Healthy blood donors & $0.05 \%$ \\
\hline Sallander et $\mathrm{al}^{23}$ & Healthy blood donors & $0.7 \%$ \\
\hline \multirow[t]{2}{*}{ Bojadzieva et al 24} & Blood donors and hospitalised patients & $9.37 \%$ \\
\hline & Multiple transfused patients & $1.28 \%$ \\
\hline Makroo et al25 & $\begin{array}{l}\text { Volunteer donors } \\
\text { in donors' serum }\end{array}$ & $4.24 \%$ \\
\hline Myhre et al26 & in hospitalised patients & $0.52 \%$ \\
\hline \multirow[t]{2}{*}{ Richard et $\mathrm{al}^{27}$} & Alloimmunized subject & $0.46 \%$ \\
\hline & Blood Donors & $1.9 \%$ \\
\hline Winters et $\mathrm{al}^{28}$ & Transfused patients & $<1 \%$ \\
\hline \multirow{2}{*}{ Giblett et al ${ }^{29}$} & Military veterans & $0.32 \%$ \\
\hline & Random donors & $1.58 \%$ \\
\hline Tormey et $\mathrm{al}^{30}$ & Blood donors & $2.4 \%$ \\
\hline Zhu et $\mathrm{al}^{31}$ & Donors population & $0.28 \%$ \\
\hline Yeela et $\mathrm{al}^{32}$ & & $0.99 \%$ \\
\hline Garcia et $\mathrm{al}^{33}$ & Pregnant females & $0.72 \%(\mathrm{AA})$ \\
\hline & Hyperbilirubinaemic Neonates & $0.23 \%(\mathrm{CSAA})$ \\
\hline Andersen et $\mathrm{al}^{34}$ & Antenatal women & $0.5 \%$ \\
\hline Wu et al ${ }^{35}$ & Pregnant women & $.01 \%(\mathrm{MA})$ \\
\hline Varghese et al ${ }^{36}$ & & $9.43 \%$ \\
\hline Jeremiah et al 37 & & $3.4 \%$ \\
\hline
\end{tabular}

AA: Alloantibody, CSAA: Clinically significant alloantibody, MA: Maternal antibodies

\section{DISCUSSION}

The Landsteiner's discovery opened the door to the birth of a wide spectrum of discoveries in the field of immunehaematology, blood transfusion among humans irrespective of their natives, unmatched pregnancy, legal medicine, anthropology and the discovery of other blood group systems as well. Today, there are more than 600 antigenic structures among the 30 defined blood groups of which $\mathrm{ABO} / \mathrm{Rh}$ blood grouping is most important and commonly used. Determination of the frequency of blood groups in a particular region facilitates safe and timely provision of blood and blood products. Blood groups are also known to have some association with diseases like duodenal ulcer, diabetes mellitus, urinary tract infection, $\mathrm{Rh}$ and $\mathrm{ABO}$ incompatibility of newborn.

As in our study, maximum number of blood donors belonged to younger age group; similar results were reported by other studies.[1-2] Basically, the younger age groups are main work force for any of the society. So, they are the most common age group encountered in donating blood. Also many of the older people suffer from hypertension, diabetes mellitus, low haemoglobin and ischaemic heart diseases and hence may abstain from donating or considered unfit during pre-donation counselling.

Similar to the present study, male predominance was also documented by some other authors also.[1-3] In developing countries because of social taboo, cultural habits, lack of motivation and fear of blood donation, female donors may be very less. In addition, large numbers of females from the menstruating age groups are anaemic with low weight, so declared unfit for blood donation and eliminated by the predonation screening. Another reason is deferral of females because of the overall prevailing prevalence of anaemia among the females all over India.
An individual blood group today is as important as the national identity card. Blood groups are genetically determined and the incidence of ABO and Rh genes and their phenotypes vary widely across races and geographical boundaries, despite the fact that the antigens involved are stable throughout life. Many studies have been conducted to know the distribution pattern of $\mathrm{ABO} / \mathrm{Rh}$ grouping, the most common blood group system, in various regions or populations within India as well as all over the world (Table 2). Most of the studies from northern, western and central part of India showed predominance of blood group 'B', while in southern and eastern parts blood group ' $O$ '. Other countries like Britain, USA, Nigeria and Sudan showed the highest frequency of blood group ' 0 ', while some countries like Pakistan, Bangladesh and Iran showed the highest frequency of blood group 'B'. A few studies like in Turkey and Nepal reported the maximum frequency of blood group ' $A$ ' in contrast to our study (Table 2).

Irregular antibodies are all non-ABO antibodies, although the main use of the term is for non-ABO isoantibodies that may cause incompatibility in blood transfusions. These antibodies can also cause a series of immunologic effects in recipients, commonly being alloimmunisation, allergic reactions and haemolytic transfusion reactions. Greater prevalence of irregular antibodies has been documented in pregnancy, multiple transfusions, haemolytic diseases of newborn and previously sensitized individuals (Table 3). Importance of irregular antibody screening in females may be explained by immunization through pregnancy, greater immune response and more exposure through transfusion. Except Anti-D in females, other antibodies can also cause a significant proportion of alloimmunisation of women and haemolytic disease of new born. There is paucity of literature on the prevalence of irregular antibodies in general population. Although in the present study, no positive result during 
irregular antibody screening of healthy blood donors; however, considerable effort has been done to detect as many different "irregular" antibodies as possible and some studies have shown a very low incidence of irregular antibodies in general population and healthy blood donors (Table 3).

In conclusion, distribution pattern of $\mathrm{ABO} / \mathrm{Rh}$ blood group typing in a particular population or region is important in safe transfusion, but routine irregular antibody screening in healthy blood donors may not be fruitful in this region keeping cost effectiveness, increased laboratory workload and absence of previous sensitization in mind. However, further larger well designed studies are needed for elaboration of importance of antibody screening of healthy blood donors, which may be necessary for better use of donor blood, more efficient services as well as safe and compatible blood transfusion, especially for previously alloimmunised individuals.

\section{REFERENCES}

1. Patel P, Patel S, Shah J, et al. Frequency and distribution of blood groups in blood donors in Western Ahmedabad-a hospital based study. National Journal of Medical Research 2012;2(2):202-6.

2. Kotwal U, Raina TR, Sidhu M, et al. Distribution of ABO \& $\mathrm{Rh}$ (D) blood groups among blood donors of Jammu region with respect to various ethnic groups. Journal of Medical Thesis 2014;2(1):31-4.

3. Deshpande RH, Wadde SK. Distribution of blood groups in blood donors in blood banks of Latur. Sch J App Med Sci 2013;1(4):276-9.

4. Gangwar V, Kumar D, Khan FA, et al. Frequency and distribution of $\mathrm{ABO}, \mathrm{RH}$ blood groups amongst the population of Uttar Pradesh. Int J A PSBMS 2012;1(4):332-4.

5. Kumar P, Maurya S, Rai V. Distribution of ABO and Rh(D) blood groups among Koari (Backward Caste) population of Jaunpur district. Anthropologist 2009;11(4):309-10.

6. Patni S, Yadav A. Blood groups among the Bhoksa of Vikasnagar block of Dehradun, Uttaranchal. Anthropologist 2003;5(2):137-8.

7. Mondal B, Maiti S, Biswas BK, et al. Prevalence of haemoglobinopathy, $\mathrm{ABO}$ and rhesus blood groups in rural areas of West Bengal, India. J Res Med Sci 2012;17(8):772-6.

8. Behra R, Joshi YR. Distribution of ABO blood groups and RH(D) factor in Western Rajasthan. National Journal of Medical Research 2013;3(1):73-5.

9. Warghat NE, Sharma NR, Baig MM. ABO and Rh Blood group distribution among Kunbis (Maratha) population of Amravati district, Maharashtra-India. Asiatic Journal of Biotechnology Resources 2011;2(04):479-83.

10. Itgappa $M$, Chandrappa MS, Nadigere MV, et al. Variation of $\mathrm{ABO}$ and $\mathrm{Rh}$ blood groups among medical students of SSIMS \& RC, Davanagere, Karnataka, India. International Journal of Pharmaceutical and Clinical Research 2011;3(4):70-2.

11. Das PK, Nair SC, Harris VK, et al. Distribution of ABO and Rh-D blood groups among blood donors in a tertiary care centre in south India. Trop Doct 2001;31(1):47-8.

12. Gupta NK, Dadwal S. Distribution of ABO and Rhesus-D blood groups. Asian J Trans Sci 2012;6(1):73.
13. Mahmood MA, Anjum AH, Tarin SMA, et al. Pattern of ABO \& RH blood groups in Multan Region. Biomedica 2005;21:1-4.

14. Sultana R, Rahman Z, Helali AM, et al. Study of ABO and RH-D blood groups among the common people of capital city of Bangladesh. Int $\mathrm{J}$ Pharm \& Pharm Sci 2013;5(3):814-6.

15. Pramanik T, Pramanik S. Distribution of $A B O$ and $R h$ blood groups in Nepalese medical students: a report. East Mediterr Health J 2000;6(1):156-8.

16. Akinnuga AM, Bamidele O, Amosu AM, et al. Distribution of $\mathrm{ABO}$ and $\mathrm{RH}$ blood groups among major ethnic groups of medical students of Madonna university teaching hospital, Elele, Nigeria. Asian Journal of Medical Sciences 2011;3(3):106-9.

17. Hassan FM. Frequency of ABO, subgroup $A B O$ and Rh(D) blood groups in major Sudanese ethnic groups. Pakistan Journal of Medical Research 2010;49(1):21-4.

18. Torun YA, Kaynar LG, Karakükcü C, et al. ABO and Rh blood group distribution in Kayseri province, Turkey. Turk J Haematol 2012;29(1):97-8.

19. Ghasemi N, Ayatollahi J, Zadehrahmani M, et al. Frequency of $\mathrm{ABO}$ and $\mathrm{Rh}$ blood groups in middle school students of Yazd province. Iranian Journal of Paediatric Haematology and Oncology 2008;1(1):27-30.

20. Mollison PL, Engelfriet CP, Conteras M. The Rh blood group system. In: Blood Transfusion in Clinical Medicine. $9^{\text {th }}$ edn. Oxford: Black well Scientific Publication, 1993:2008-9.

21. Frances TF. Blood groups (ABO groups). In: common laboratory and diagnostic tests. $3^{\text {rd }}$ edn. Philadelphia, Lippincott, 2002:19-5.

22. Pahuja S, Kushwaha S, Sethi N, et al. Screening of blood donors for erythrocyte alloantibodies. Haematology 2012;17(5):302-5.

23. Sallander S, Shanwell A, Aqvist M. Evaluation of solid phase test for erythrocyte antibody screening for pregnant women, patients and blood donors. Vox Sanguinis 1996;71(4):221-5.

24. Bojadzieva MT, Blagoevska M, Kolevski $\mathrm{P}$, et al. Optimal blood grouping and antibody screening for safe transfusion. Prilozi 2009;30(1):119-28.

25. Makroo RM, Riana V, Rosamma NL, et al. Detection of alloimmunization to ensure safer transfusion practice. Asian Journal of Transfusion Science 2013;7(2):135-9.

26. Myhre BA, Greenwalt TJ, Gajewski M. Incidence of irregular antibodies occurring in healthy donor sera. Transfusion 1965;5:350-4.

27. Iammarino RM. Incidence of irregular antibodies in a general hospital. Technical bulletin of the registry of medical technologists 1966;36(10):243-5.

28. Winters JL, Pineda AA, Gorden LD, et al. RBC alloantibody specificity and antigen potency in Olmsted County, Minnesota. Transfusion 2001;41(11):1413-20.

29. Giblett ER. Blood group alloantibodies: an assessment of some laboratory practices. Transfusion 1977;17(4): 299-308.

30. Tormey CA, Fisk J, Stack G. Red blood cell alloantibody frequency, specificity and properties in a population of male military veterans. Transfusion 2008;48(10): 2069-76. 
31. Zhu JY, Lan JC, Luo HQ. Screening analysis of irregular antibodies from random donor population in Shaouguan area. Zhongguo Shi Yan Xue Za Zhi 2007;15(3):630-1.

32. Yeela T, Buathong W. Screening and identification of irregular antibodies in blood donation. Songkla Med J 2004;22(2):89-93.

33. Garcia MA, Bautista L, Palomino F. Should blood donors be routinely screened for irregular antibodies. Immunohematology 2012;28:60-5.

34. Andersen AS, Praetorius L, Jorgensen HL, et al. Prognostic value of screening for irregular antibodies late in pregnancy in rhesus positive women. Acta Obstet Gynaecol Scand 2002;81(5):407-11.
35. Wu KH, Chu SL, Chang JG, et al. Haemolytic disease of the newborn due to maternal irregular antibodies in the Chinese population in Taiwan. Transfusion medicine 2003;13(5):311-4.

36. Varghese J, Chacko MP, Rajaiah M, et al. Red cell alloimmunization among antenatal women attending a tertiary care hospital in south India. Indian J Med Res 2013;138(1):68-71.

37. Jeremiah ZA, Mordi A, Buseri FL, et al. Frequencies of maternal red blood cell alloantibodies in port Harcourt, Nigeria. Asian Journal of Transfusion Science 2011;5(1):39-41. 